\title{
SPORT AND THE CHILD WITH A LEARNING DISABILITY
}

\author{
G. D. VAN DER MERWE, B.A., B.Ed., T.O.D. (Spec. Ed.)
}

Die kind met leergestremdheid, uiteenlopend van aard, vind deelname aan sport dikwels moeilik. Dit kan egter sy lewenservaring verbreed mits dit binne sy persoonsmoontikhede geskied. Finaliteit oor die besonderhede van deelname moet nog bereik word.

The child is presented as a physical-mental-spiritual whole to the adult responsible for his education. It is the duty of the educator, namely the parent, teacher, therapist or psychologist to educate the child as whole.

The school educates the child by means of didactic methods (transmitting knowledge), orientation (establishing a choice reference) and socialisation (social mobilisation). Thus the child is led to social emancipation during schooling by creating opportunities to enlarge his experience in a competitive environment; to develop a social conscience leading to selfdiscovery and fulfilment; and to meet the opposite sex in a learning situation.

Social mobility is achieved through formal teaching in the classroom, extra-curricular activities and development of a community spirit in which extra-curricular activities play a part.

It is particularly with extra-curricular activities such as eisteddfods, debating societies or sport that the child with learning disability has difficulty in coping. Participation in these extra-curricular activities presents problems and makes demands on the person concerned with the education of such children.

The problem situation is intensified by the diversity of learning disabilities. Some pupils have multiple learning disabilities, which cannot be ascribed to a single factor. The pupil's learning disability may result in:

Emotional disturbances, expressed in behavioural terms such as emotional immaturity, hyperactivity, passivity, a sense of insecurity and lack of protection, a feeling of inferiority, infantility and regression.

Mental and emotional crippling expressed as a lack of the following: initiative and drive; sense of duty; perseverance, willpower and endurance; reliability and responsibility; experience of authority; independence and cooperation.

Social immobility as a result of aggression or being withdrawn; being uncontrolled or passive; a lack of selfconfidence or unrealistic bravado; cheekiness; sensitivity; destructiveness; excessive jealousy; a tendency to pilfering, truancy and lying.

If the above is accepted as guidance, then the following aspects of education, as regards the participation in sport by the child with a learning disability, can

* Head of Department, West Rand School for Cerebral Palsied. be highlighted.

\section{Acceptance of own body}

Man explores his world through his body. He manipulates his world and, moves in it. One of the ideal goals of education is the acquisition of definite selfknowledge by the child. This can only be realised if the child has discovered his situation in his world as a whole. However, the child will only be able to discover himself by noting what happens in his world and to him.

It is the task of the educator to guide a child with learning disability, who is often handicapped in approaching his world, in such a way that he develops a positive selfimage; acquires his own identity, leading to acceptance of his own sexuality, mental ability and specific talents; arrives at moral judgement on physical matters and creates relationships with others in various situations.

\section{Development of positive selfimage}

Establishment of a positive selfimage implies knowledge of the peripheral components of his personality structure, such as interest, possible social qualities and emotions. The child is capable of selfdistancing, implying that he judges his own behaviour, that he has selfknowledge and knows his own disability and ability.

Establishment of moral values in relation to the physicef

With due regard to the development of the child's moral awareness, his participation in sport must be guided towards acceptance of values such as altruism, fairness, tolerance, discipline and honesty.

\section{Creating interpersonal relationships}

Acquaintance with the world of his fellowmen depends on his being made to feel at home in it. The child's participation in sport will give the educator the opportunity to guide him so that he learns responsible fellowship and also to compete with other pupils within moral limits; to accept authority and order; to utilise his spare time in a meaningful and creative manner; and to accept a proper girl-boy relationship.

The above are some features to be taken into account when the educator plans sport for the child with learning disability. Particular attention is necessary to avoid a situation where the child's participation in sport leads to development of a negative selfimage and to frustration expressed as aggression, to uncontrolled behaviour and to lack of selfconfidence. Participation 
in sport should lead to a sense of duty, a show of initiative and drive, as well as perseverance, willpower, endurance, reliability and responsibility.

A sport programme should be planned so that each child can participate within his limitations whilst it is still acceptable to teachers and therapists. This is a complex problem, considering that therapists, psychologists and teachers have been meeting annually for the past five years to decide whether children with learning disability should participate in sport, which items should be included and what effect it would have on the children.

Thus far no clear answer has emerged. as diverse opinions render a solution impossible. The author does not doubt the educational value of sport. In the near future a decision will have to be taken about which items are to be offered, who should participate and how achievements should be calculated and recognized, albeit by means of research, discussion or trial and error.

\section{Sources}

1. Gunter, C. F. G. (1967): Aspekte van die teoretiese opvoedkunde, Stellenbosch. Universiteits Uitgewers.

2. Hamilton, J. H. (1971): Die verstandelikgestremde leerling. Stellenosch, Universiteits Uitgewers.

3. Landman, W. A., Roos, S. G. en Liebenberg, C. R. (....): Opvoedkunde en opvoedingsleer vir beginners. Stelenbosch, Universiteits Uitgewers.

4. Sonnekus, M. C. H. (1978): Die psigiese lewe van die kind met spesifieke leergestremdhede (In: Leerlinge met spesifieke leergestremdhede in skole van die Departement van Nasionale Opvoeding. Simposium 11 - 13 Oktober 1978).

5. Van der Stoep, F. en van der Stoep, O. A. (1968): Didaktiese oriëntasie. Pretoria. Academica.

6. Van Niekerk, P. A. (1978): Wie is die kind met spesifieke leergestremdhede? (In: Leerlinge met spesifieke leergestremdhede in skole van die Departement van Nasionale Opvoeding. Simposium 11-13 Oktober 1978) 